\title{
El sol sale por el Oeste
}

\section{The sun rises in the West}

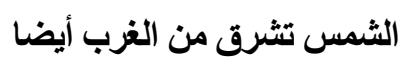

د. حسناء بوزويتة الطر ابلسي

Hasna TRABELSI

Profesora de Literatura Andalusí, Universidad de Túnez

hasna.trabelsi@yahoo.fr

Recibido: octubre 2010

Aceptado: mayo 2011

\section{RESUMEN}

En este artículo presento las contribuciones de los estudiosos musulmanes occidentales sobre las relaciones Este/Oeste, destacando el sentimiento de los estudiosos de inferioridad hacia los orientales, que ha crecido convirtiéndose en una especia de complejo frente a todo aquello que viene del Este. Aún así, los estudiosos andalusíes, consciente de la necesidad de ir más allá de este complejo y de revalorizar la personalidad andalusí y sus destacadas contribuciones, se esforzaron en incluir su patrimonio en antologías y enciclopedias. Analizo estas contribuciones basándome en algunos textos del libro de Abu-1-Walid al-Himyari (440/1048-49), Al Badi’ fi wasf ar -Rabi’.

Palabras clave: estudiosos musulmanes de Occidente, Al-Qayrawan, Al-Andalus, personalidad andalusí, poesía andalusí, Al-Badi fi wasf ar-Rabi. Al-Himyari.

\begin{abstract}
In this study I present the contributions of Occident muslim scholars in the East/West cultural relations highlighting the scholars' feelings of inferiority towards Orientals, which have grown into a kind of complex vis-à-vis whatever comes from the East. However, the Andalusian scholars, aware of the necessity to go beyond this complex and valorize the Andalusian personality and its outstanding contributions, strive to include their patrimoine in anthologies and encyclopedias. I discuss these contributions on the basis of some texts from Abu- 1-Walid al- Himyari's book (440/1048-49), Al Badi' fi wasf ar-Rabi'.
\end{abstract}

Key words: Occident muslim scholars. Al-Qayrawan. Al-Andalus. Andalusian personality. Andalusian poetry. Al-Badi fi wasf ar-Rabi. Al-Himyari.

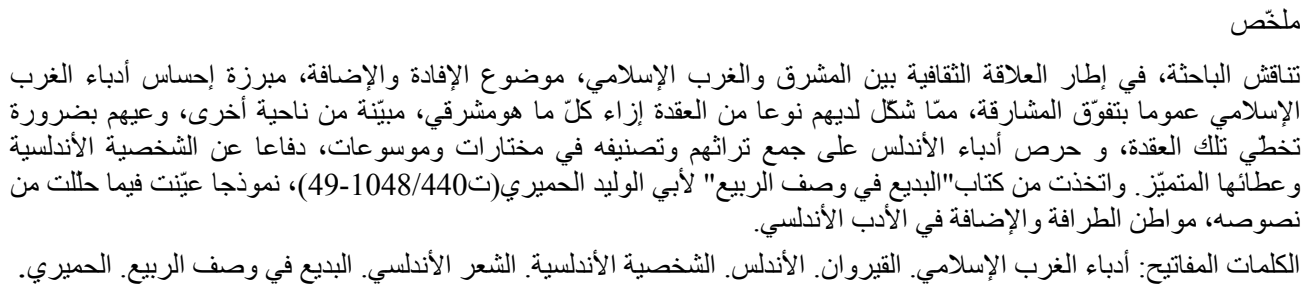




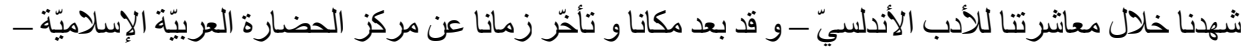

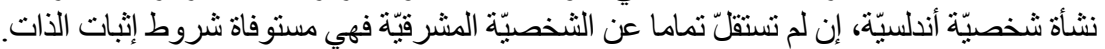

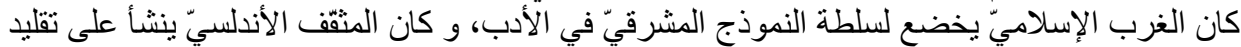

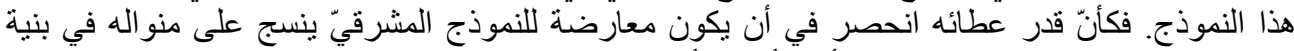

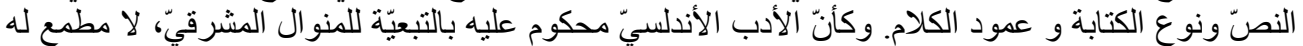

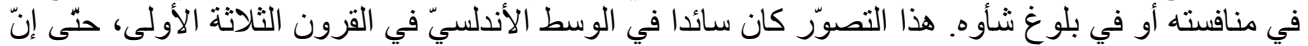

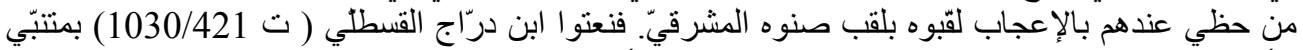

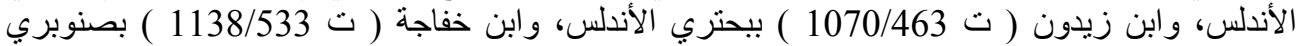

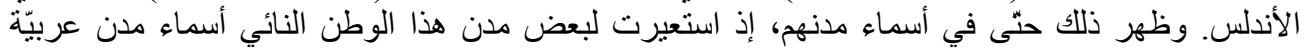

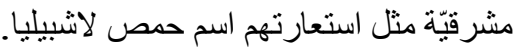

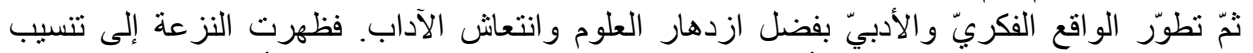

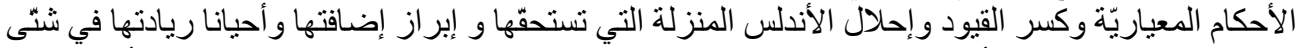

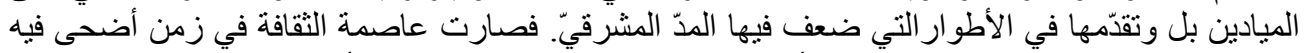

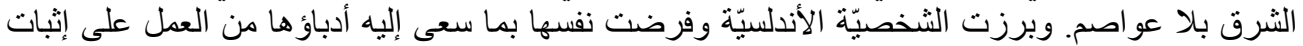
الهويّة الأندلسيّة و التغلب على عقدة مشرق / مغرب.

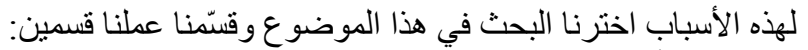

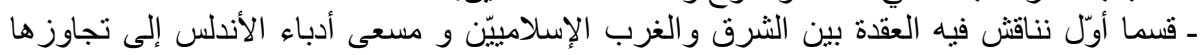

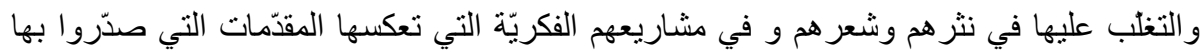
مؤلفاتهم. ـ و قسما ثنانيا ندرس فيه "كتاب البديع في وصف الربيع" لأبي الوليد الحميري1 نموذجا نبرز من خلاله سمات الخصوصيّة الأندلسيّة . فئية

قال ابن حزم ( ت 1063/456) من مطوّلة له في الفخر [ الطويل] : مئل

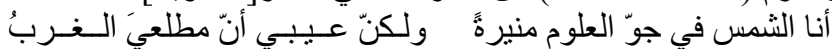

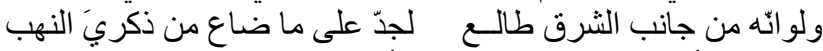

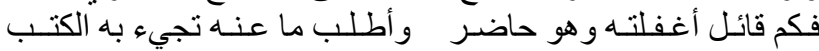

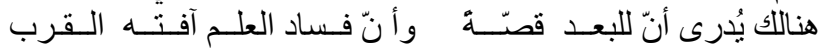

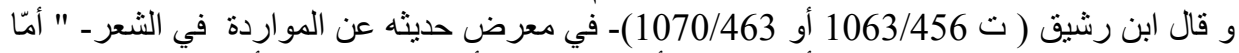

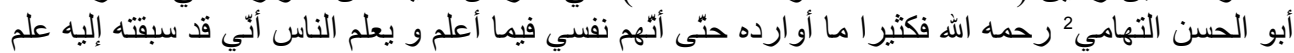

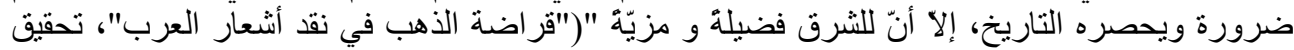

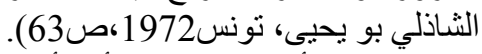
استوقفتنا أبيات ابن حزم، أحد أساطين الفكر و الأدب بأندلس القرن الخامس للهجرة و والبيت الأوّل منها

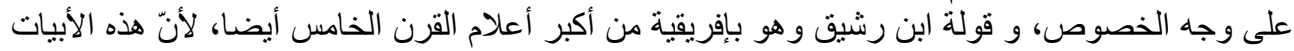

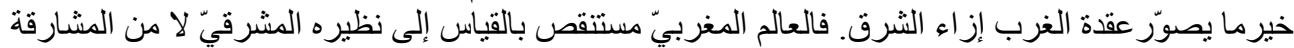

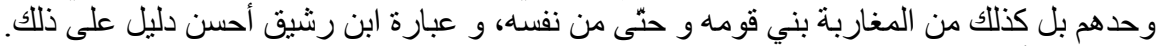

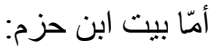
أنا الشمس في جوّ" العلوم منيرةً و و لكنّ عيبي أنّ مطلعيَ الغربُ

1 تحقيق هنري بيريس، الرباط 1940. 2 شاعر من نهامة عاش بين الثام و العر اق ومصر (ت1025/416)، لم يحفظ له التاريخ سوى 168بيت(ابن رشيق، قر اضة 


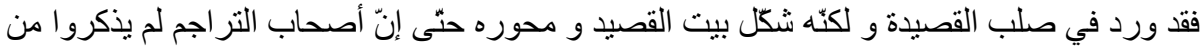

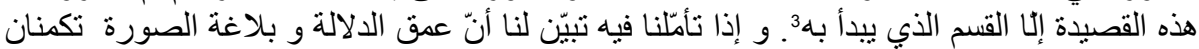

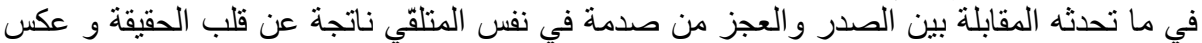

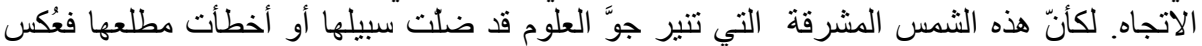

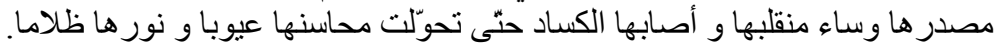

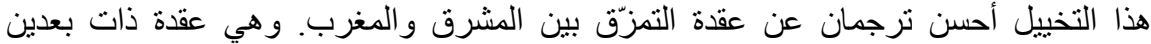

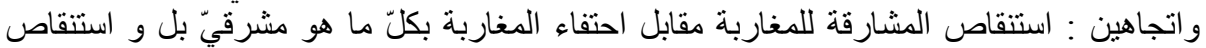

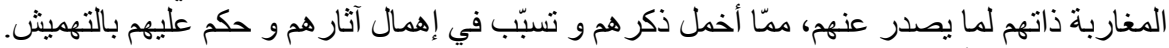

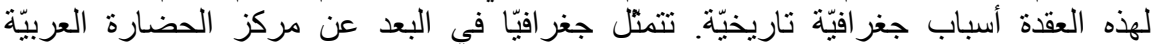

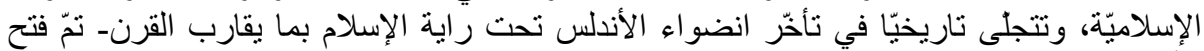

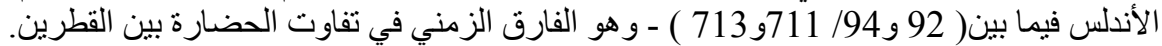

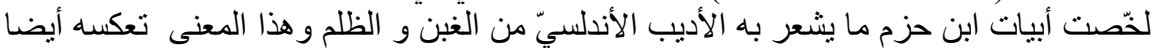

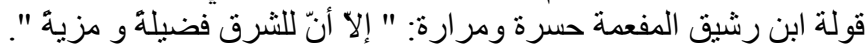

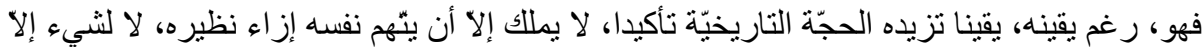
لأئّه مغربيّ و رو الآخر مشرفيّ.

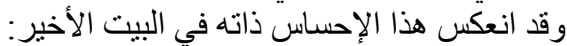

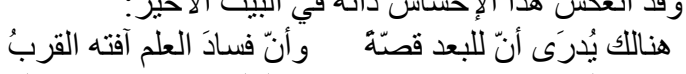

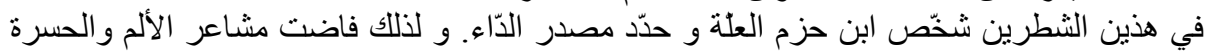
في نفس كلّ من الأديبين، فصدحا بهذه العبار ات التي لهات التهن من اكتناز اللفظ وبعد المرمى ما يجعلها

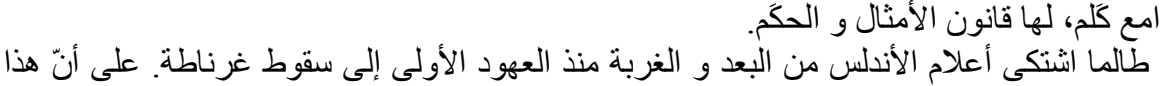

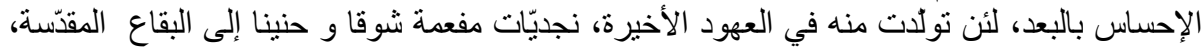

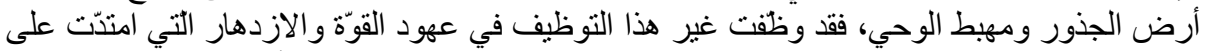

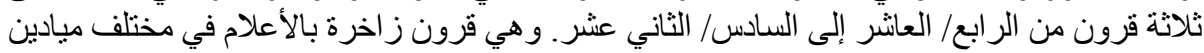

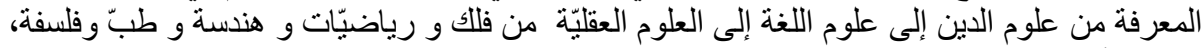

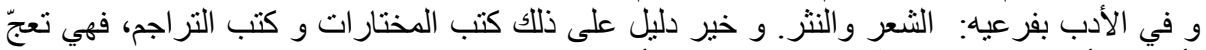

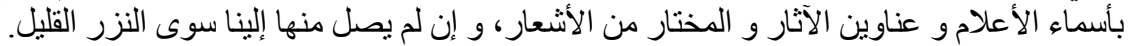

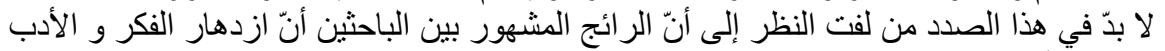

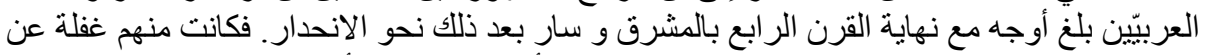

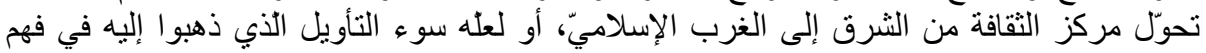

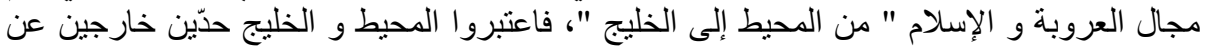

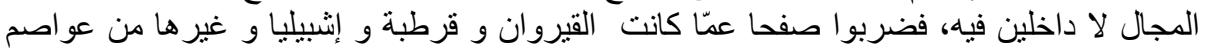

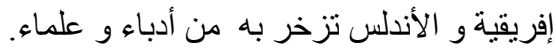

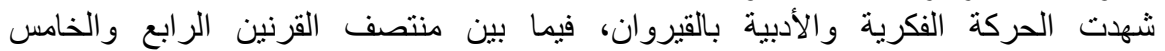
بالخصوص، نشاطا وازدهار ا كبيرين بلغا أوجهما في ظلّ حكم المعزّ بن باديس (

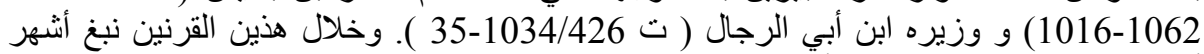

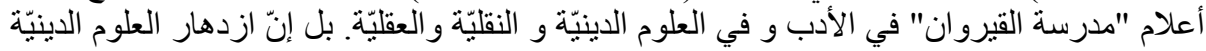

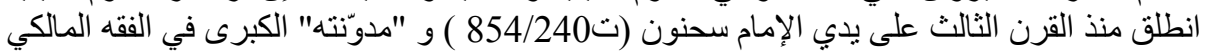

3 انظر القصيدة كاملة فيما حققه محمد الهادي الطر ابلسي من شعر ابن حزم ونشره لاؤّل مرّة، حوليّات الجامعة التونسية، عدد 9، 
وابن أبي زيد القيرواني ( ت 996/386 ) الملقب بـ"مالك الأصغر". و من أبرز أعلام مدرسة

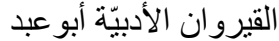

1- قال عبد الرحمان الداخل(138-756/172-788)، أول أمراء الدولة الأمويّة بالأندلس، وقد رأى نخلة

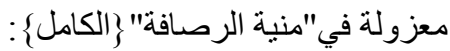

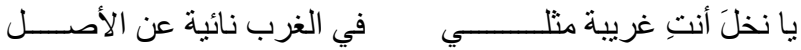

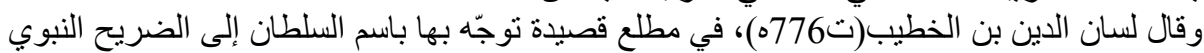

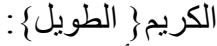

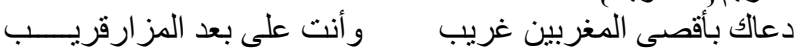

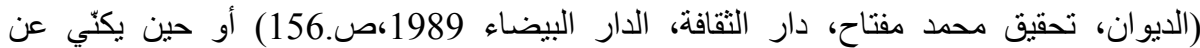
الأندلس"بالثغر الغريب" أو "بالثغز الناز حان النائي".

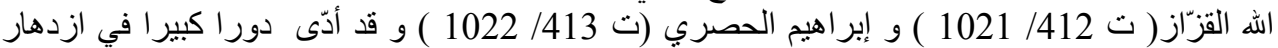

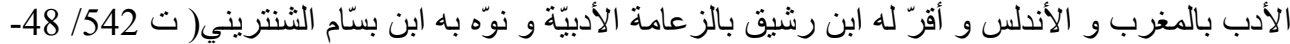

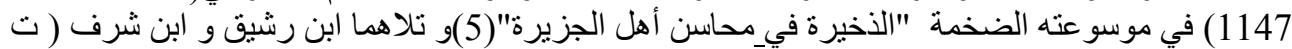

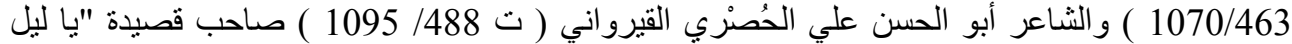

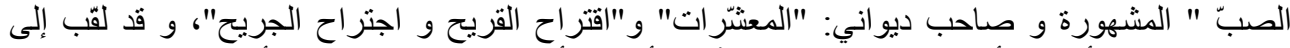

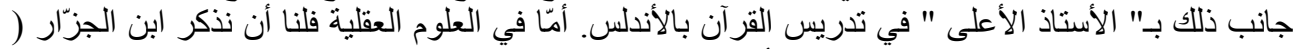

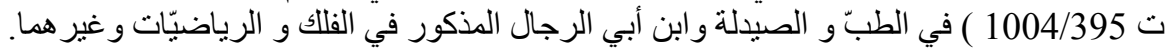

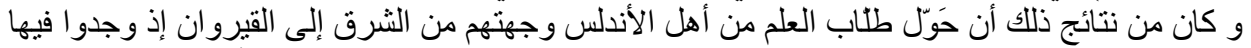

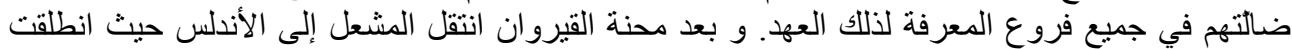

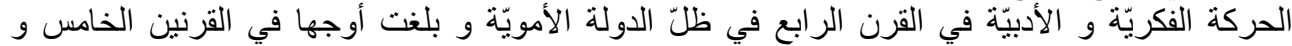

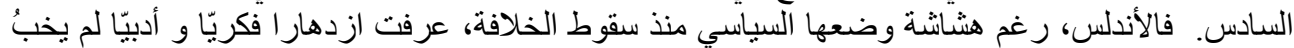

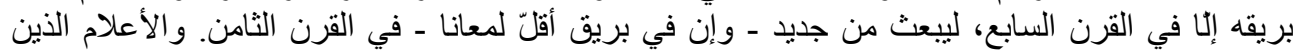

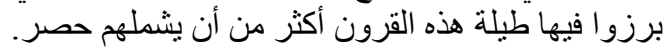

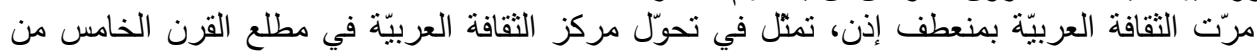

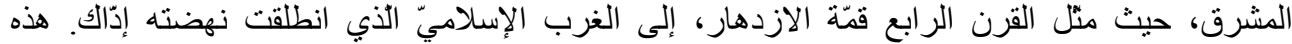

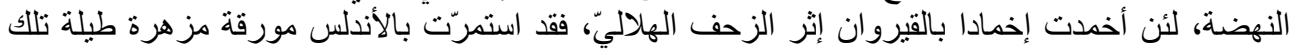

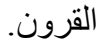

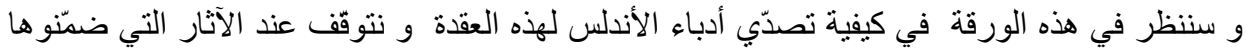

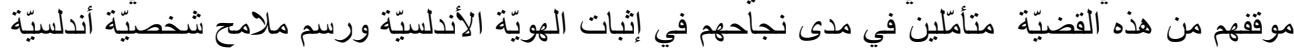

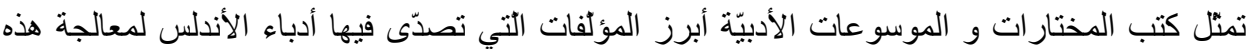

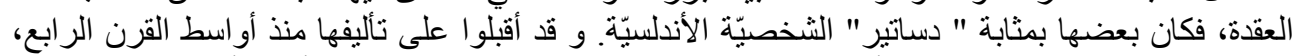

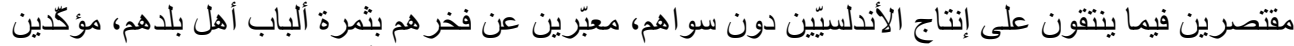

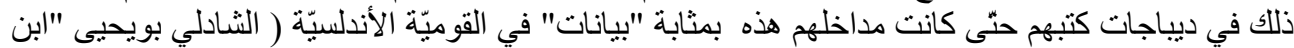

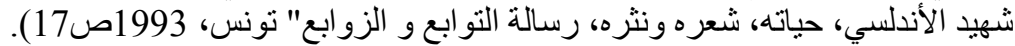

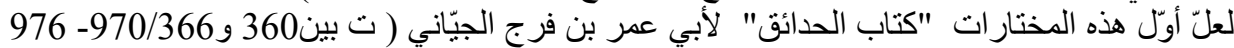

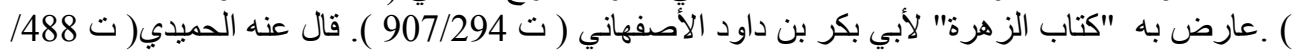

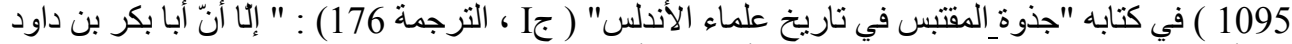

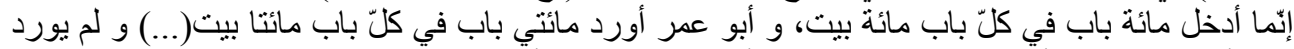

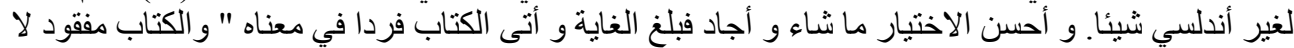

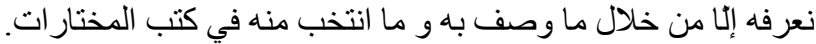


انصبّ اهتمام ابن فرج الجيّاني في كتابه هذا على الرواية لأهل عصره من الأندلسيّين دون غيرهم.

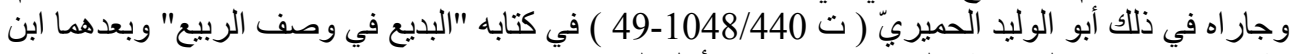

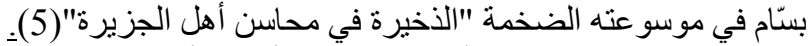

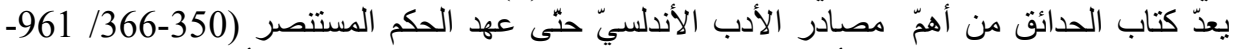

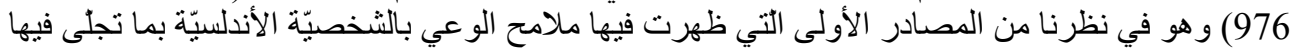

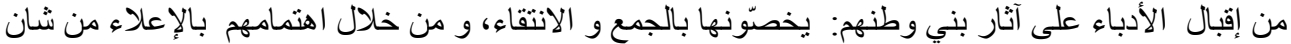

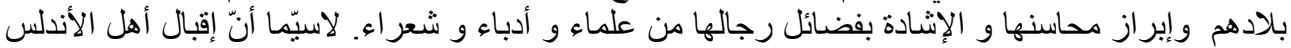

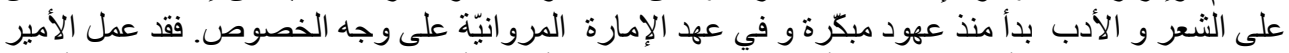

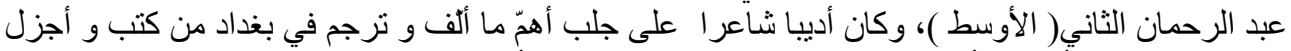

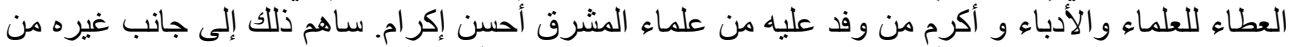

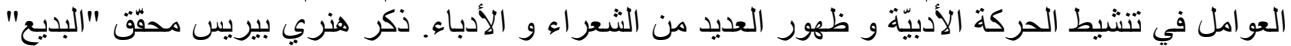

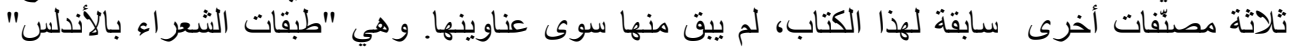

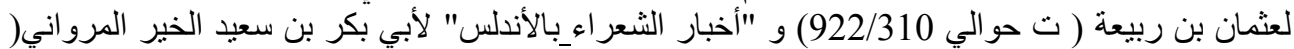

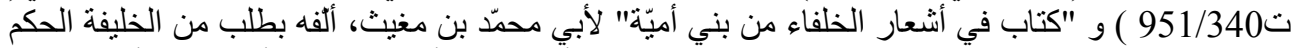

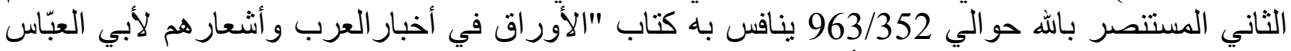

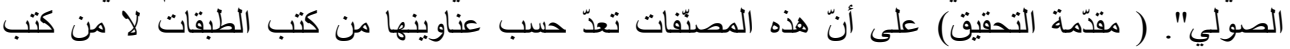

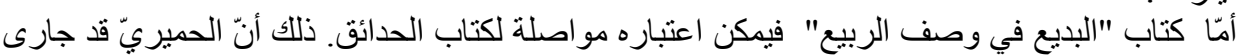

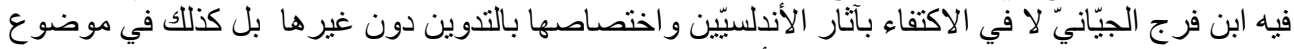

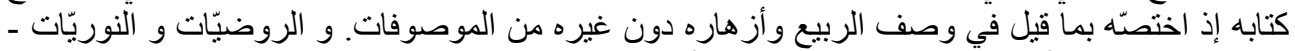

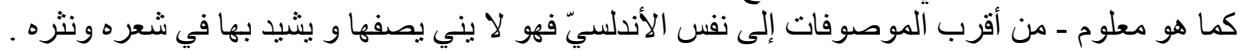

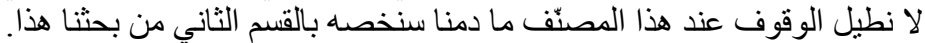

"الذخيرة في محاسن أهل الجزيرة" تحقيق إحسان عبّاس، دار الثقافة، بيروت، لبنان 1997.

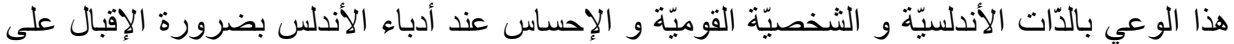

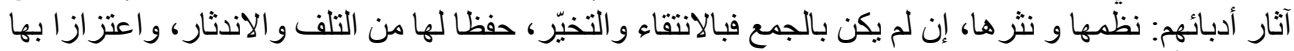

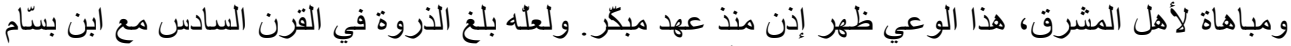

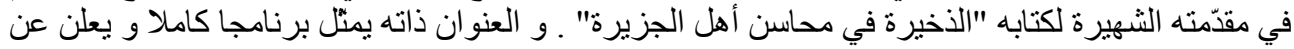

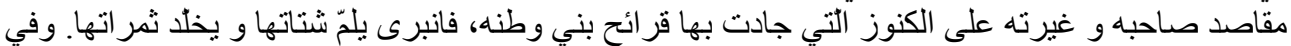

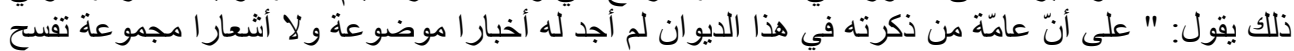

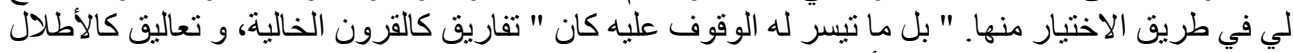

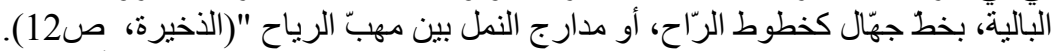

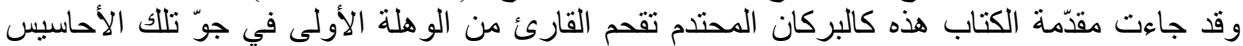

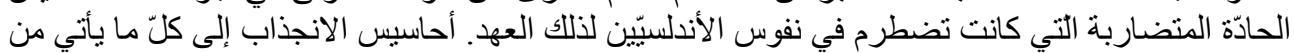

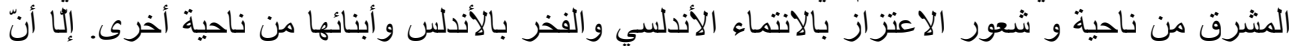

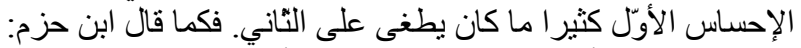

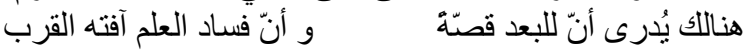

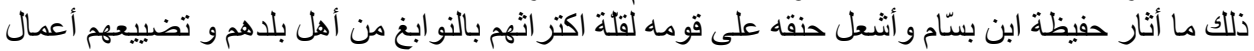

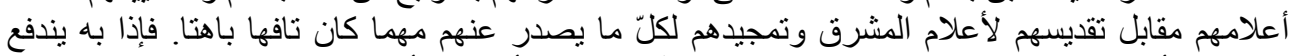

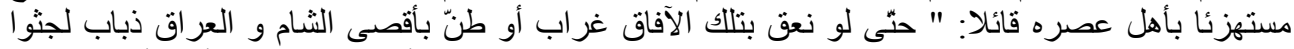

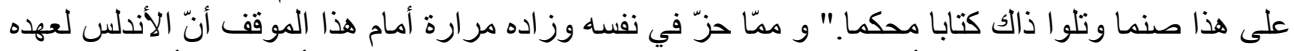

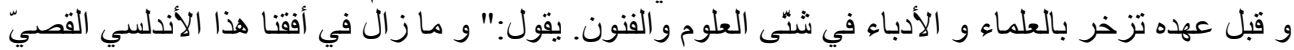


إلى وقتنا هذا من فرسان الفيّين و أئمّة النو عين قوم هم ما هم: طيب مكاسر، وصفاء جو اهر، و عذوبة موارد

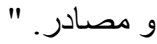

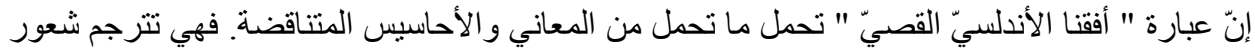

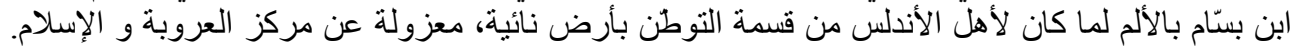

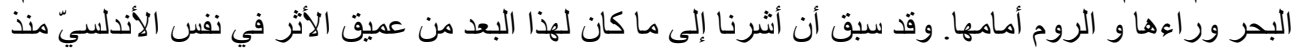

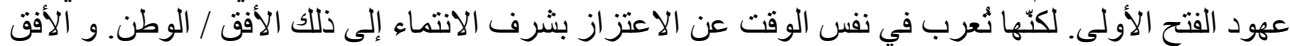
كناية عن المكان البعيد السحيق.

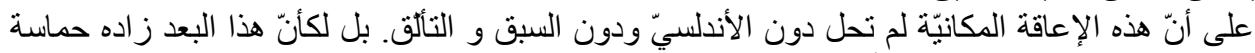

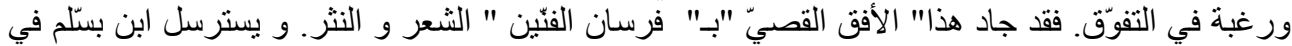

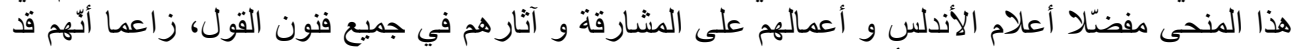

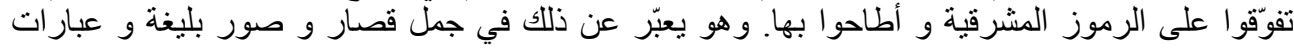

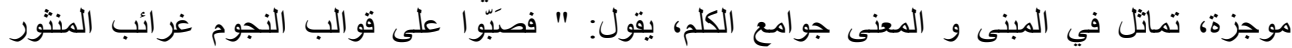

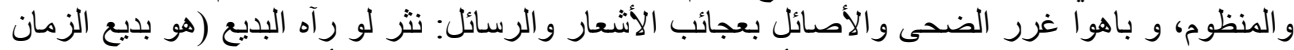

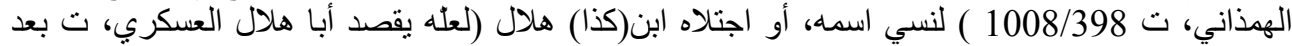

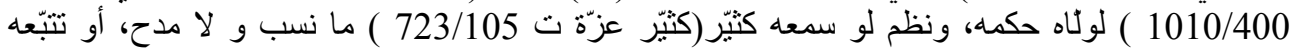

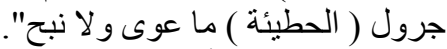

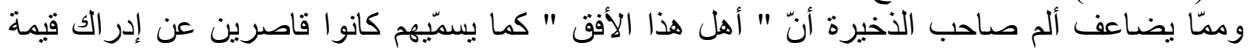

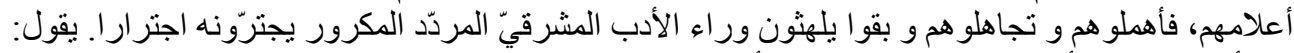

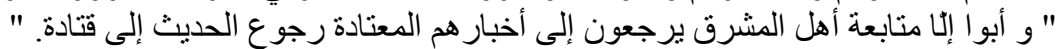

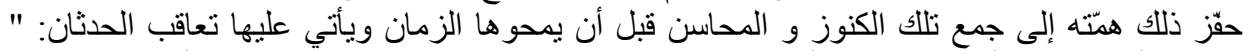

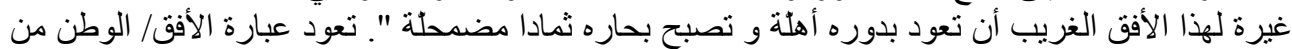

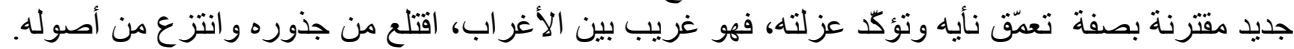

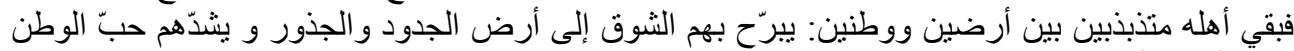

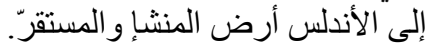

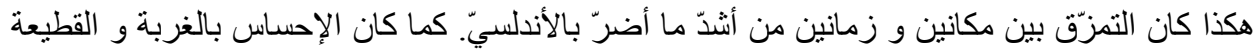

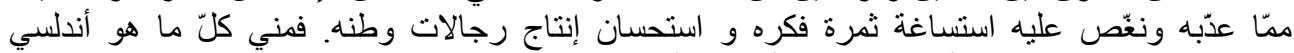

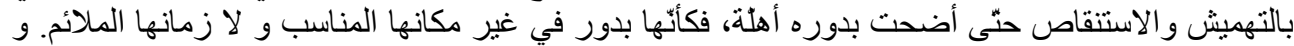

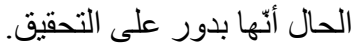
لعلّ ما يكمن وراء هذه الثورة التهّة العارمة على سلطة الأنموذج عند ابن حزم و ابن بسّام و غيرهما يقين

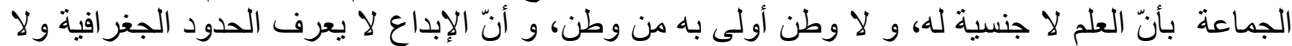

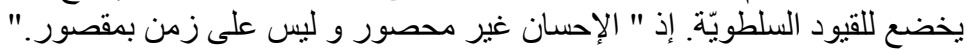

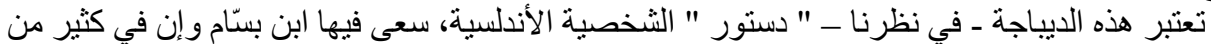

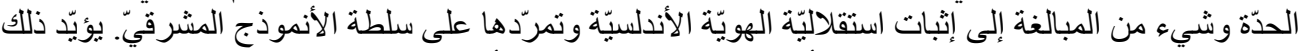

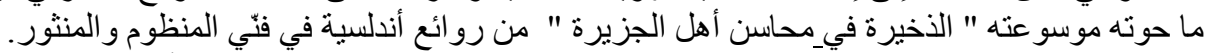

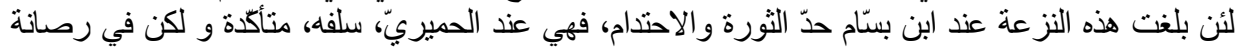

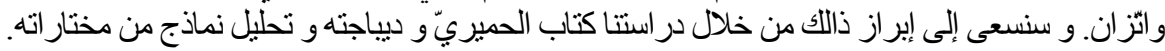

\section{"البليع في وصف الربيع" لأبي الوليل الحميري"، صورة أندلسية}

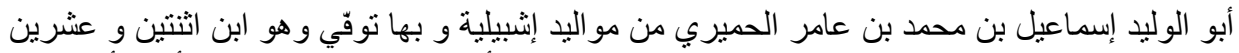

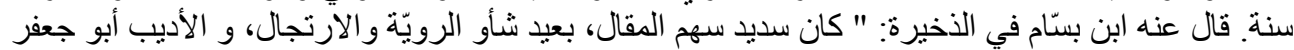


بن الأبّار هو الذي أقام قناته، وصقل مر آته، فأطلعه شهابا ثاقبا، و سلك به إلى فنون الأدب طريقا لاحبا. و لو تو تخطاه

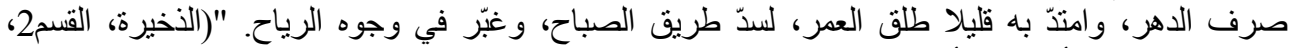

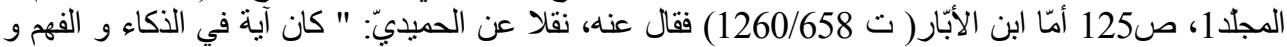

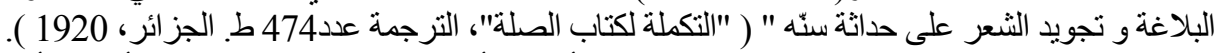

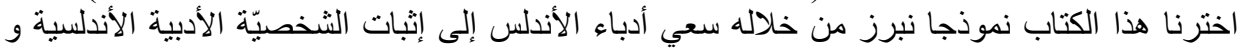

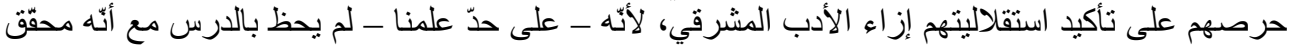

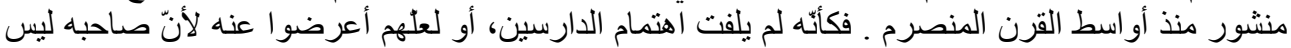

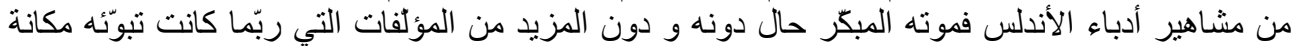

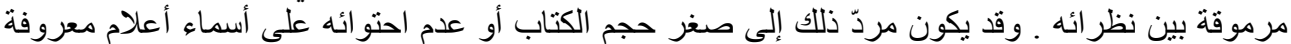

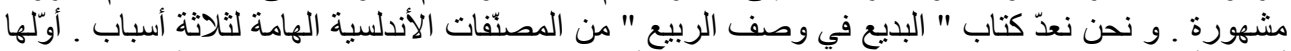

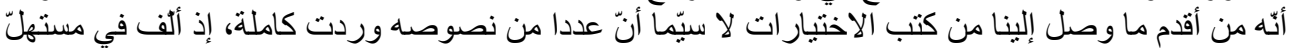

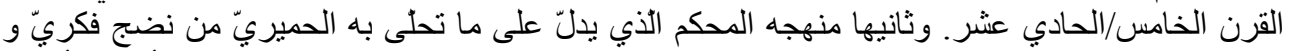

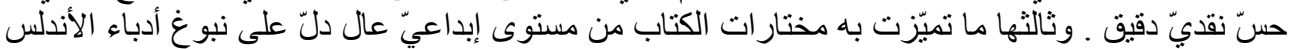

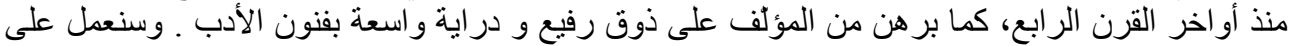

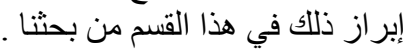

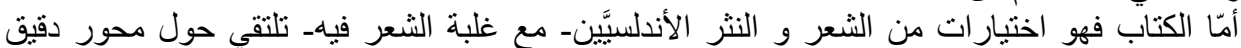

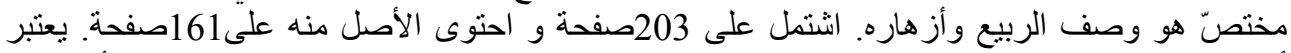

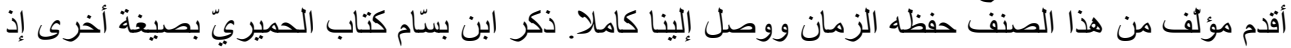

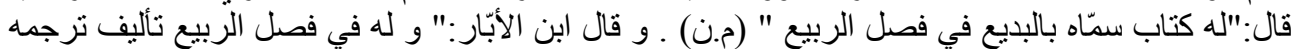

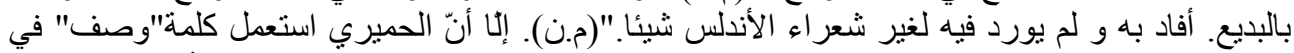

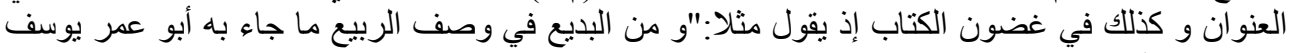

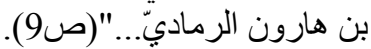

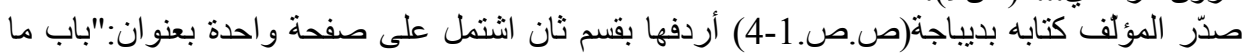

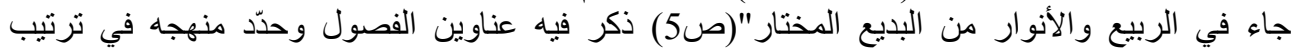

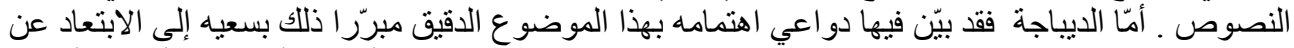

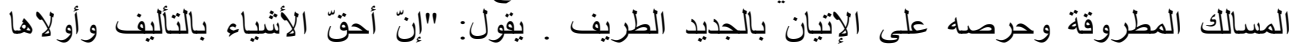

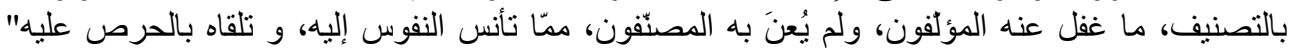

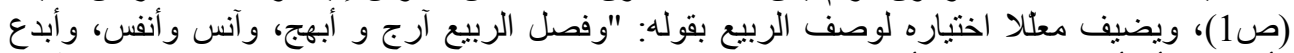

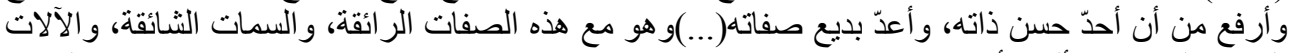

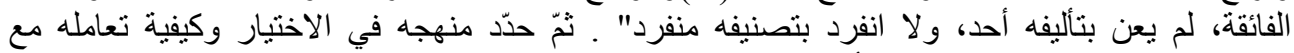

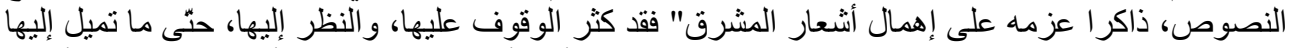

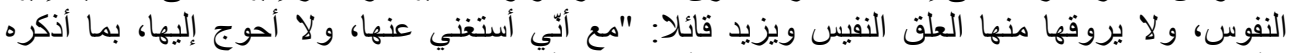

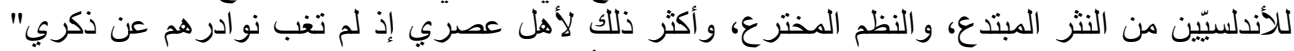

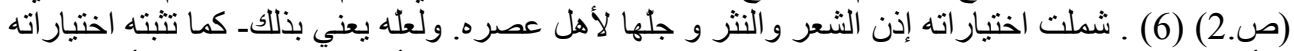

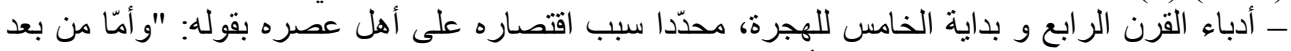

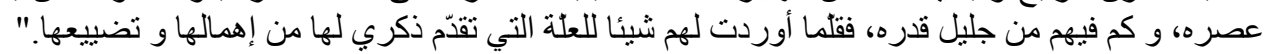

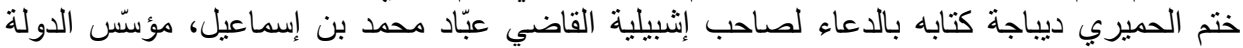

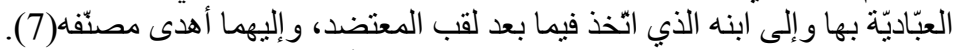

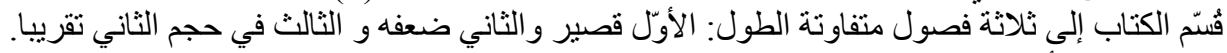

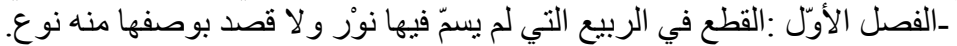

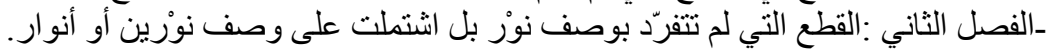
ـالفصل الثالثّ في القطع المنفردة كلّ و احدة منها بنوز على على حدة. 


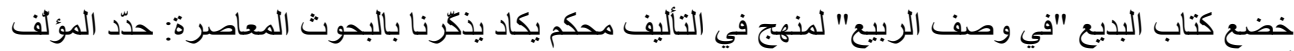
أبرز خطوطه في الديباجة بقسميها كما تقدّم بيانه، وبقي حريصا، طيلة فصول الكتاب، على التقبّ بهذه لئه

الخطوط لا يحيد عنها.

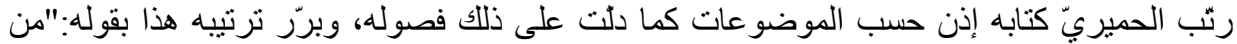

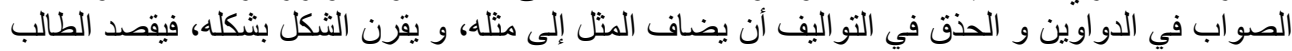

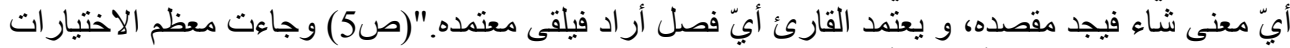

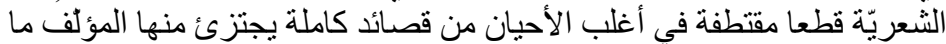

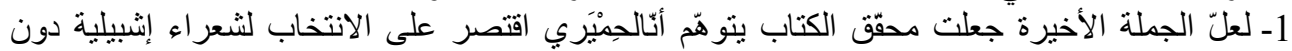

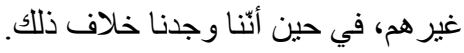

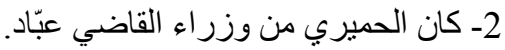

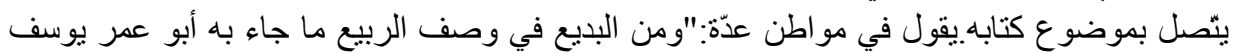

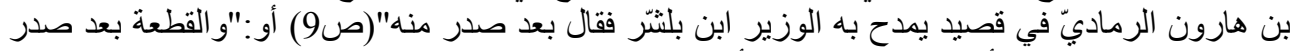

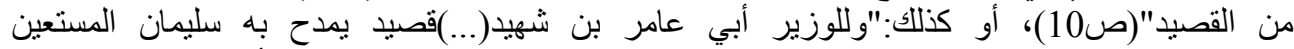

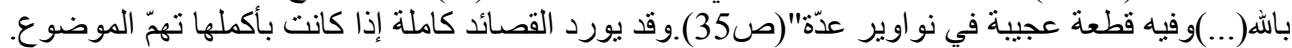

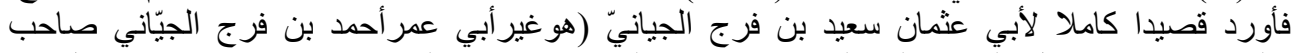

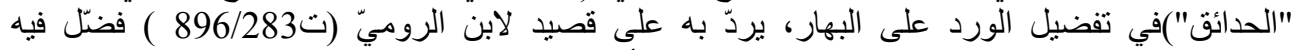

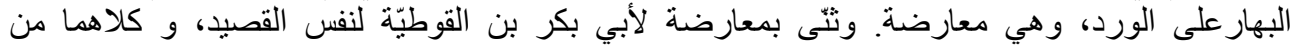

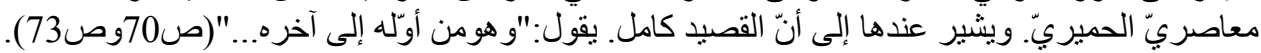

فليس الكتاب مجرّد اختيار ات بل هو في مقام مدوّنة أدبيّة انتقاها صاحبها من المصادر الأندلسية لإنجاز عمل علميّ.

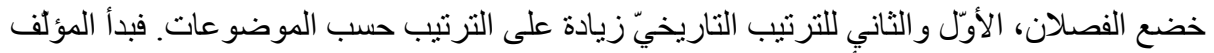

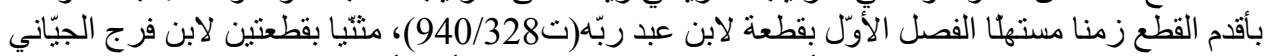

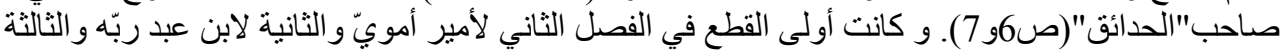

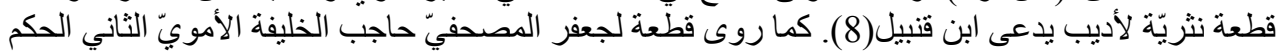

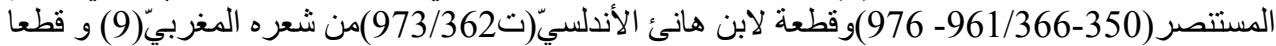

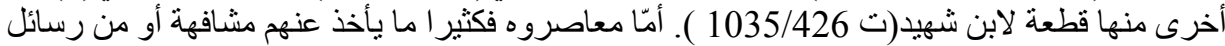
شعريّة ونثريّة يتبادلونها.

كانت نصوص الفصل الأوّل من صنف الروضيّات إذ تضمّتت وصف الرياض عموما. ومن ذلك قول

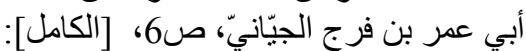

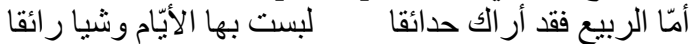

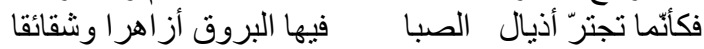

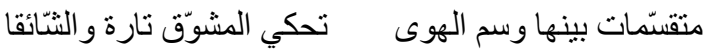

وكثير ا ما يتخلل وصف الرياض وصف الأنواء والرعود والبروق من مثل قول الرماديّ، ص11، بكت السحاب على الرياض فحسّنت منها عروسا من دموع ثكول 
1- 2- لم يعرّفه المحقق ولم نعثر له على ترجمة.

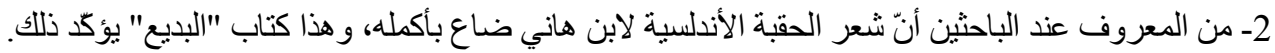

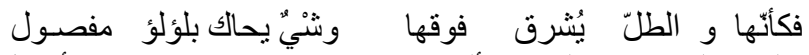

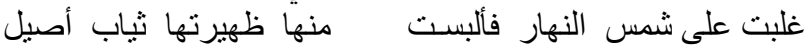

و من نصوص الفصل الثاني قول الوزير أبي عامر بن مسلمة من قطعة "تضمّتت من التشبيهات غريبها

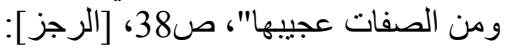

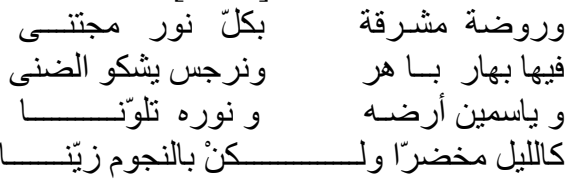

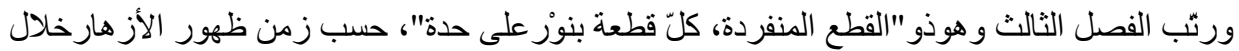

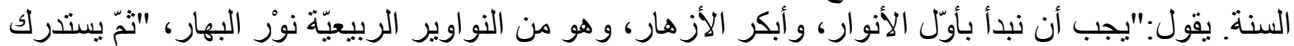

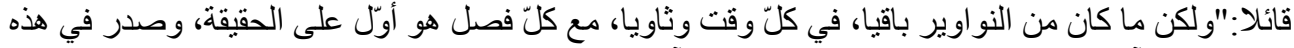

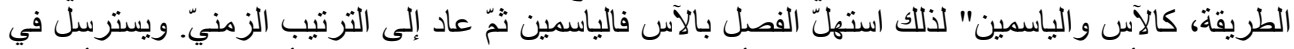

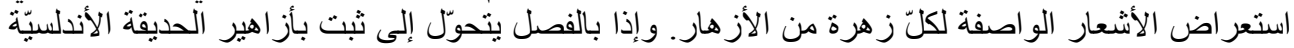

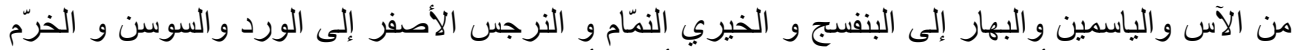

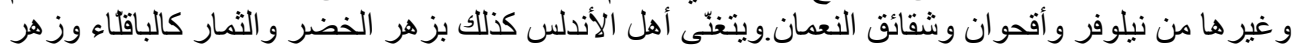
الكثّان ونوز اللوز وز هر الرمّان وهم كثيرو الثغنف بالجلنار (=ز هر الرمّان البريّ).

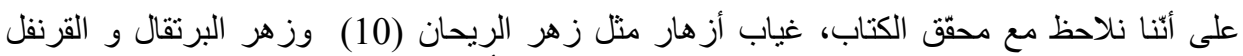

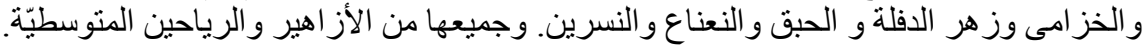

ومن خصائص منهج الاختبار عند أبي الوليد أيضا، حرصه على الئه انتقاء أجود ما بلغه من أثنعار مبرهنا

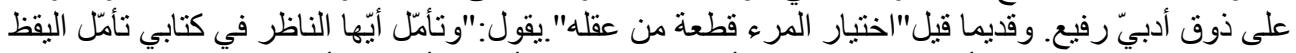

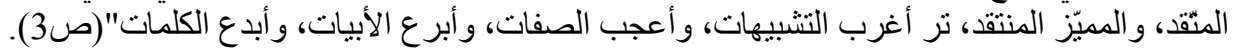

يتجلى إحكام المنهج إذن في ضبطه مقاييس الاختيار التي أخضع لها مختارات كتابه من ناحية و التزامه إلها

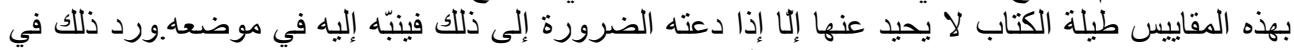

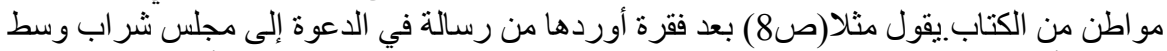

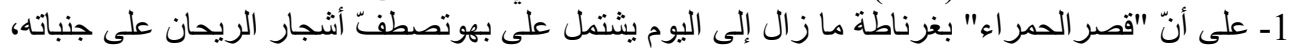

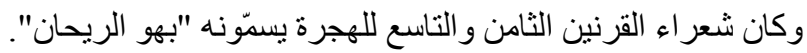

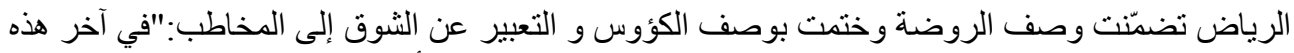

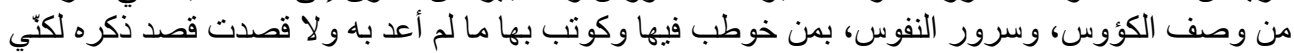

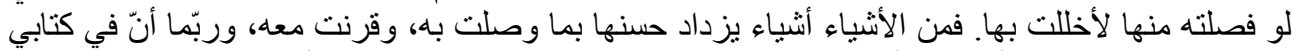

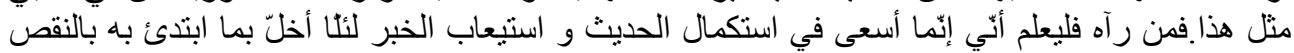

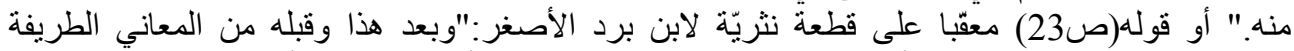

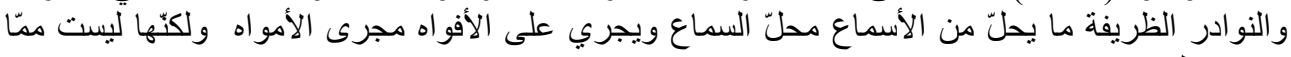
قصدت إلى جمعه و لا عنيت بذكره." 


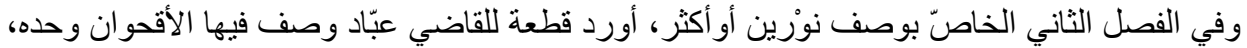

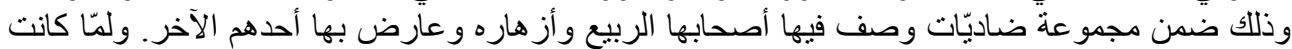

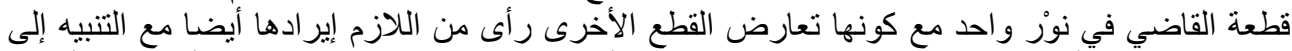

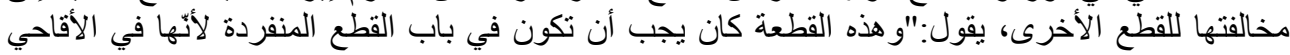

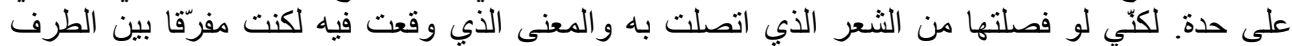

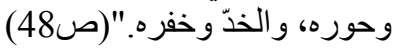

هذه الدقة وهذا الحرص على البقاء في حدود المنهج الذي بنى عليه عمله في الاختيار ، وهذا الالتزام بما

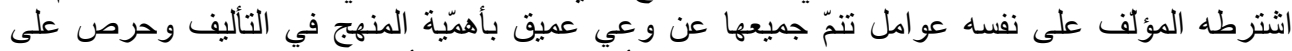

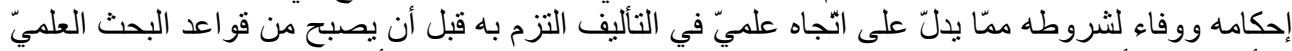

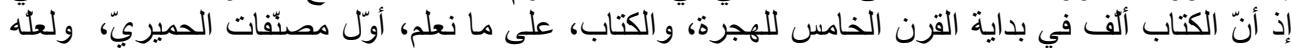
آخر ها أيضا.

من خصائص منهج التأليف أيضا تعقيب المؤلف على النصوص المنتقاة بالثروح المعجميّة للغريب

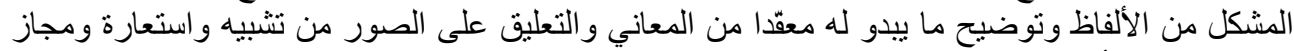

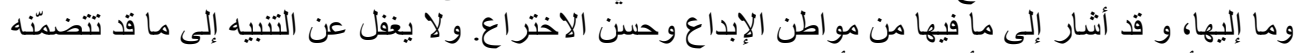

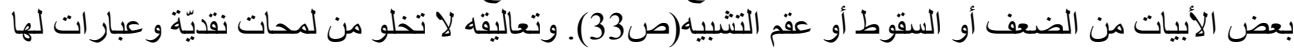

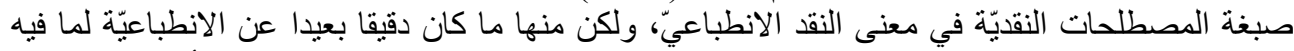

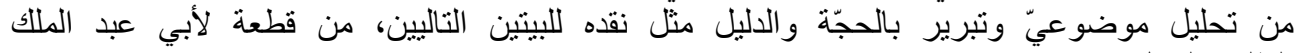

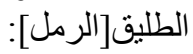

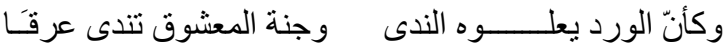

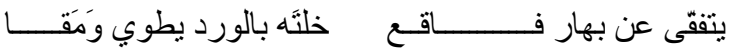

حيث يقول:"تشبيه الورد بوجنة المعشوق كثير إلّا أنّه أعرب بزيادة الندى ومقابلته بالعرق".

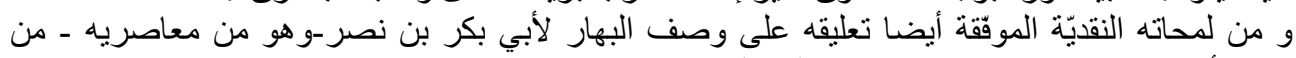

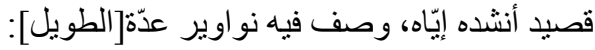

$$
\begin{aligned}
& \text { ومن نرجس نضر يروقلك درّهُ وياقوته السامي به وزبرجدُه: }
\end{aligned}
$$

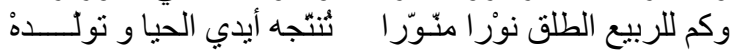

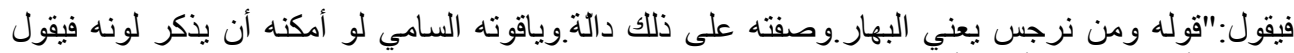

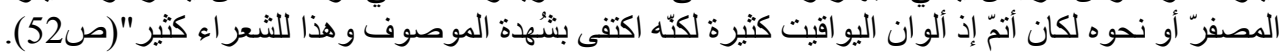

ويوازن أحيانا بين ما يتقارب من الأشعار مثل موازنته بين قول أبي بكر بن نصر هذا، وقد روى لـان له اله

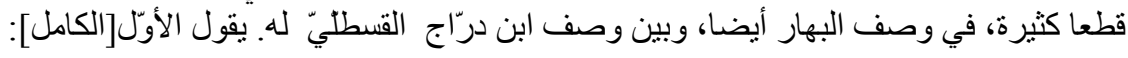

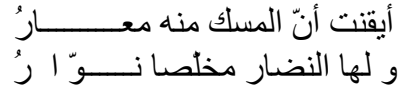

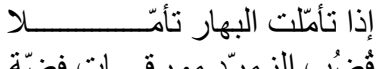

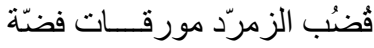

أمّا الثاني فيقول[المتقارب]: 

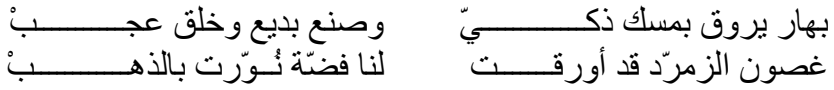

فيقول معلقا على وصف الأوّل: "أمّا وصفه البهار فهو كوصف أبي عمر القسطليّ له و يمكن أن يأخذه أو أو الأ

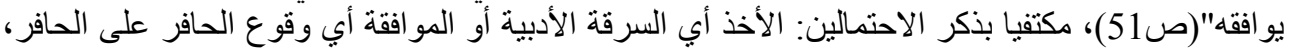

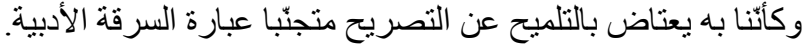

\section{الأدباء المعتمدون في الاختيار}

روى الحميريّ لأكثر من ثلاثثن شاعرا وأديبا، أقدمه زمنا ابن عبد ربّه. على أنّ الذين فازوا بأوفر

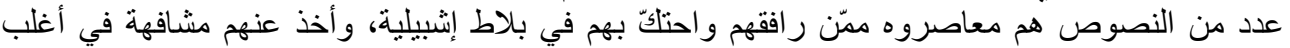

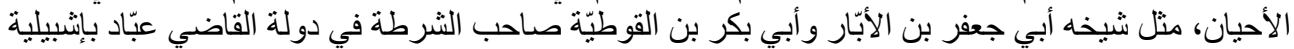

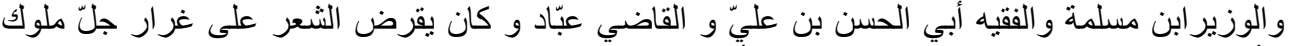

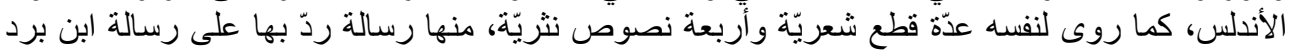

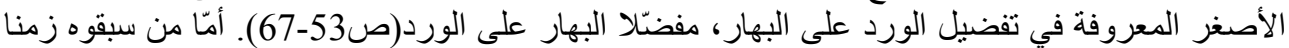

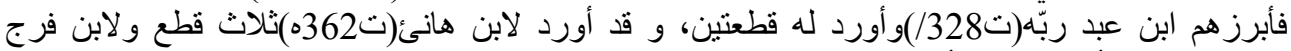

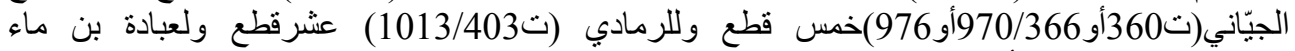
السماء(ت 1030/421)أربع قطع و لابن درّاج القسطليّ(ت (ت 1030/421)سبع قطع.

أمّا الموشّحات فلم تنل رضا أبي الوليد بل نر اه جرى مجرى غيره من أصحاب المختار ات الذين نبذوها

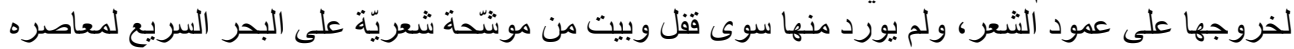

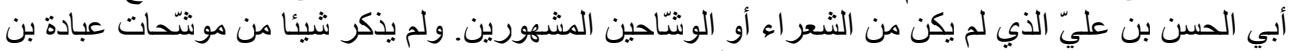
ماء السماء الوشّاح المعروف، في حين روى لهن لهن أربع قطع شعرية حسب لوني ما بينّاه.

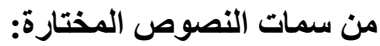

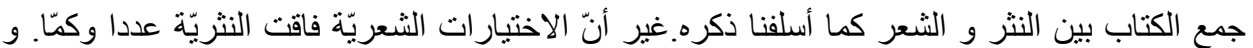

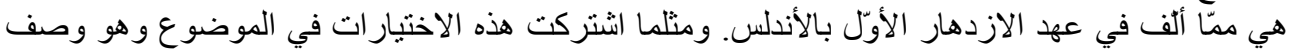

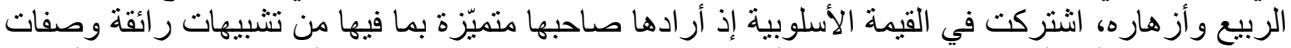

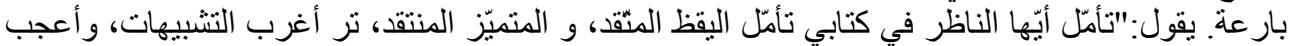

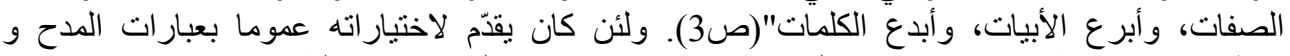

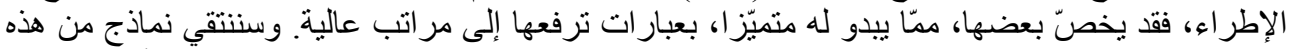

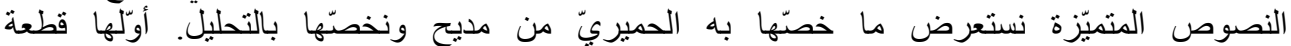

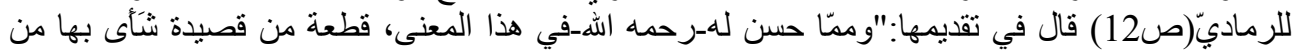
تقدّم".ومن هذه القطعة قولهـ فالطويل]:

تعجّبت من غوص الحيا في حثَا الثرى فأفنى الذي فيه ولم يتكل

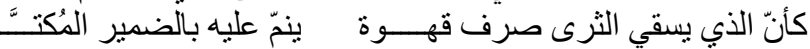


في هذين البيتين تعجّب وتعجيب:عجبّه منظر المطر يغوص في حثَا الثرى فيبعث الحياة في صمت وثبات

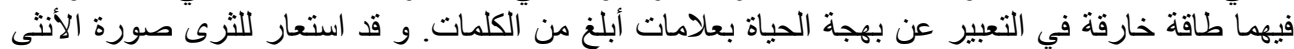

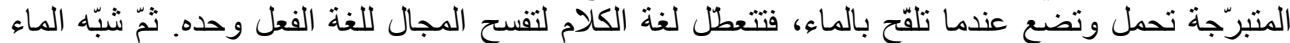

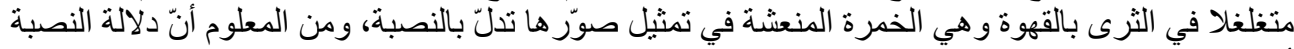

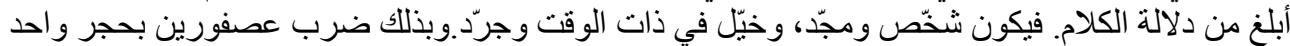

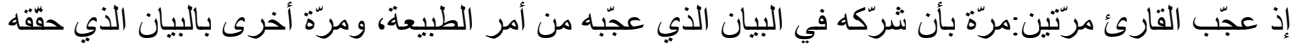

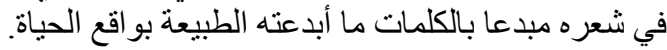

وقال في وصف قطعة لابن شهيد:"وله في الربيع قطعة عجيبة من قصيدة طويلة مشتملة على أوصاف،

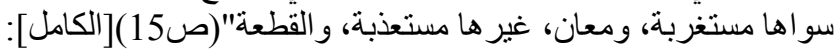
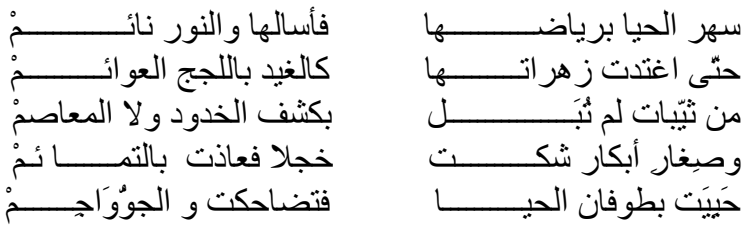

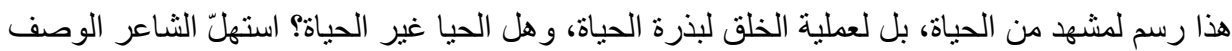

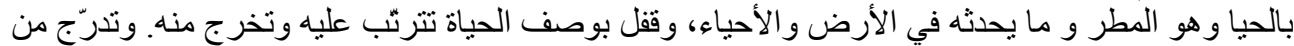

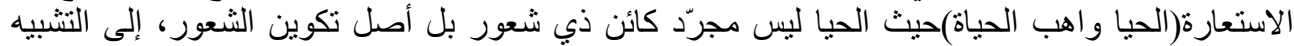

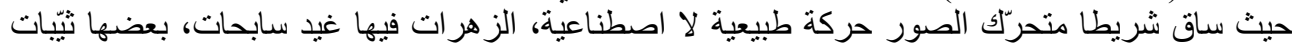

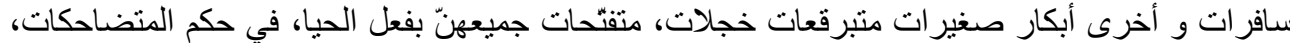

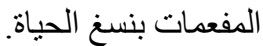

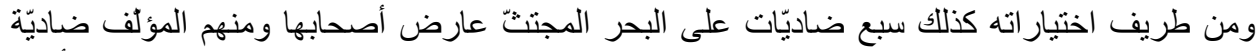

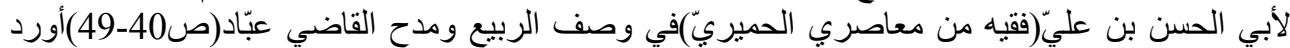
منهاً المؤلف القطع المشاكلة للموضوع. و نتنتي بدورنا مقتطفات من تلك القطع. فمن قطعة الحميريّ قوله:
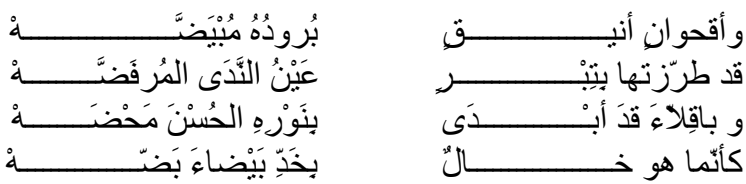

قرن أبو الوليد في الوصف بين زهرتين: زهرة الأقحوان وزهرة الباقّاء، لجامع بينهما:بياض البرود

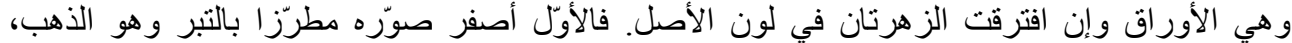

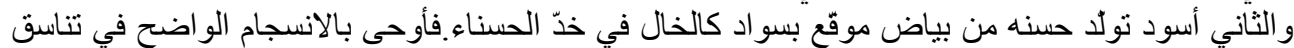

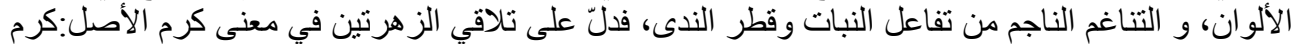
الحجر ممئلا بالتبر وكرم البشر ممئلا بالمر أن الجميلة.

أمّا قصبدة أبي جعفر بن الأبّار فنورد منها الأبيات الأربعة الأولى:

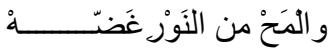

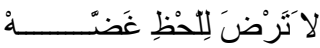



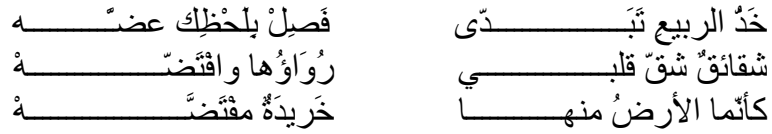

بنى الثاعر هذه الأبيات على مبدإ يعرب عن ثقافة، وانطباع يعكس تجربة، إذ تدرّج من الإنشاء أمرا ونهيا(لا ترض، المح، ص ل)إلى التقرير حيث قدّم خبر اوصوّر في النفس أثرا، مندمجا بذلك في مشهد يصفه

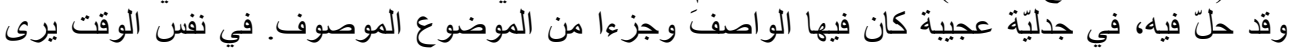

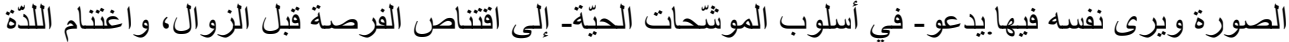

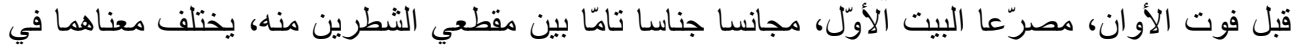

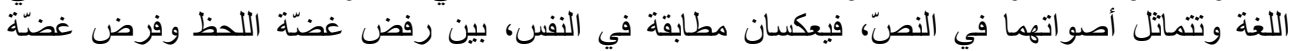

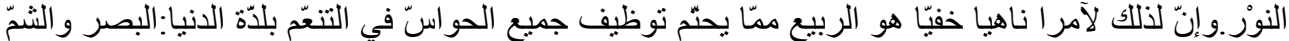

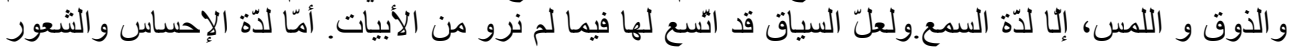

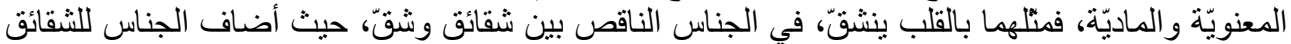

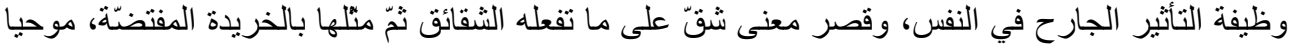

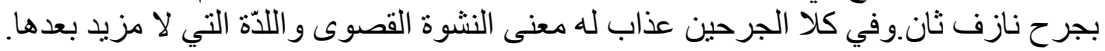

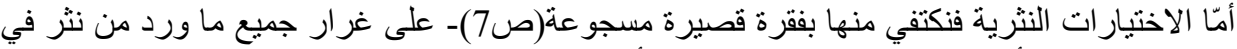

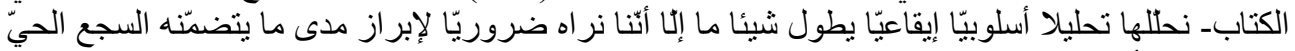

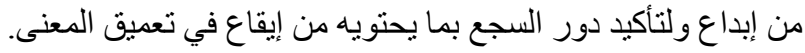

هذه الفقرة رسالة تتضمّن دعوة وجّهها صديق إلى صديق له يستقدمه في ظرف روفي رائق:الزمان ربيع

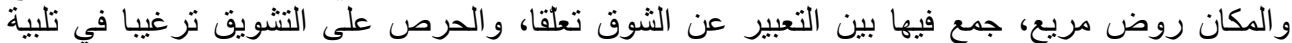

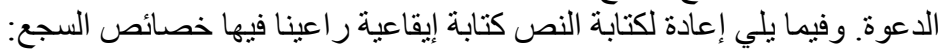

عدد المقاطع (بالوقوف على الساكن في
أو اخر الفقر على ما ما ما الفِقَر مرقمة

يقتضيه التلفظ بالسجع) كتبت إليك و الأرض بالمع (... 1- تستطير باسنطارة شوقنا إليك

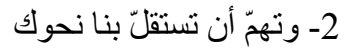
إذ صرنا بروضة استعارت... 3- لون السماء بخضرتها برونا 4- وز وزهر نجو مها بأنو ارها 5- وبدور تمّها بأقمار ها 6- افترشنا ثوب السماء 7- و احتويناز هرة الدنيا و بينا [أز هار؟ 
8- م- ولطلعة إليك بأعناق الغزلان

14 9- ولسمع حسّك مصيخة الآذان

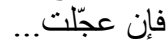
و إن أبطأت...

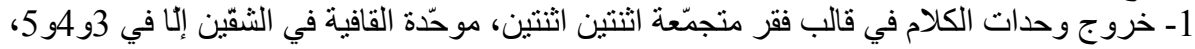

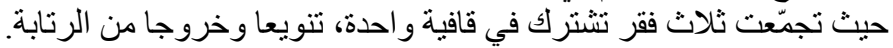

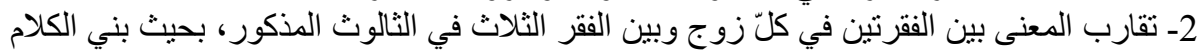

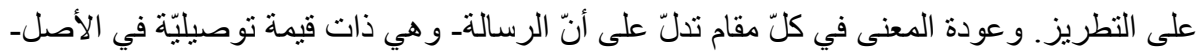

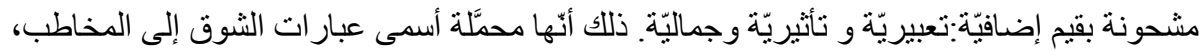

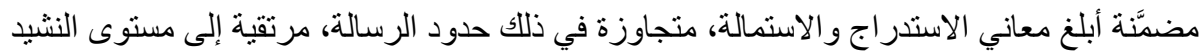
بما فيها من تمجيد.

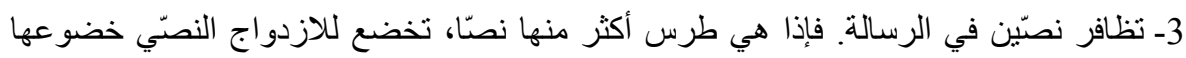

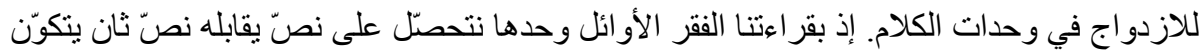
من الفقر الثو في وحي.

$$
\begin{aligned}
& \text { يتكوّن النصّ الأوّل من الفقر: 1-3-6-8-10-12-12 }
\end{aligned}
$$

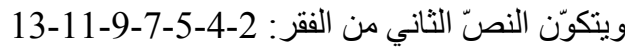

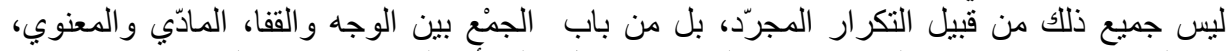

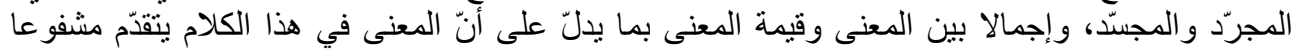

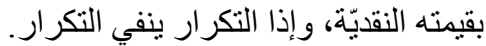

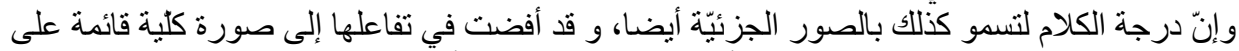

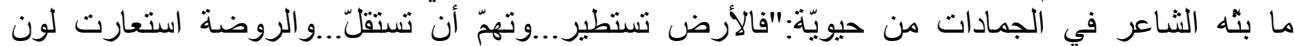

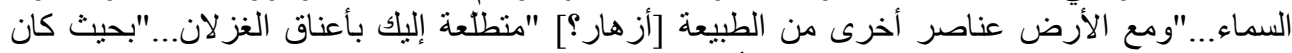

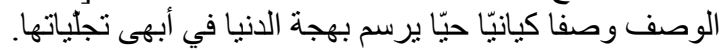

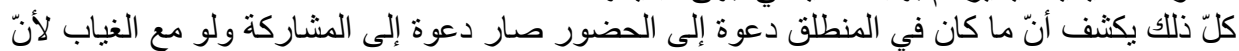

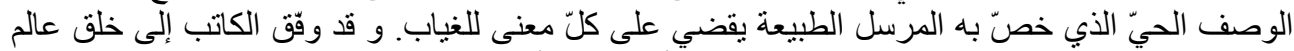
جديد عجيب تندك" الحو اجز فيه بين حدود المكان، لأنّ المكان أضحى "يستطير"، ولئ وبين حدود الزمان حيث

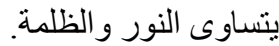

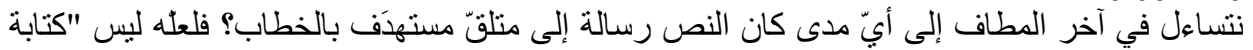

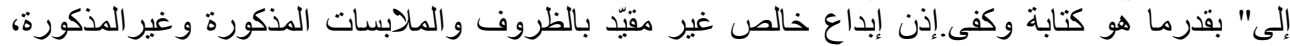

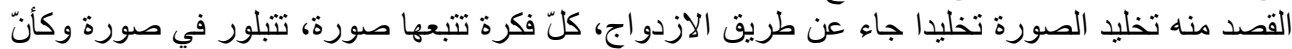

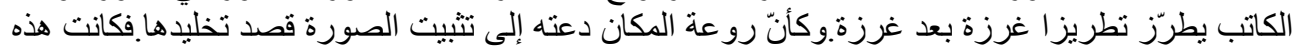

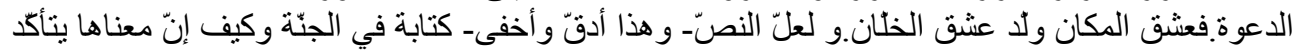
بالتأسّس، وينتفي أصلا إذا عدم فيها الخلّ الودود أو الحبيب الأنيس. 
أردنا بهذا الغوص في نماذج قصيرة من اختبار ات كتاب "البديع في وصف الربيع الربيع" أن نقدّم صورة حيّة

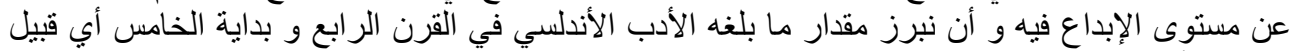

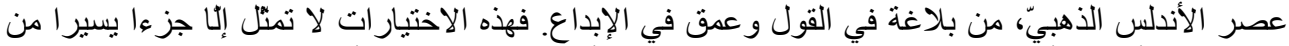

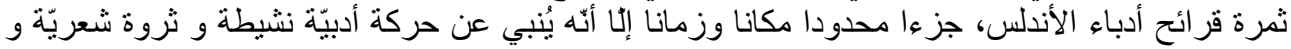
نثريّة وفيرة.

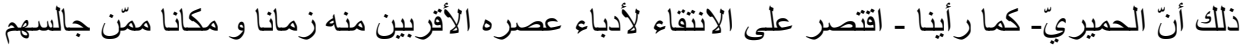

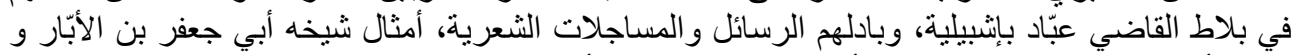

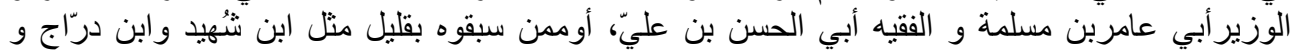

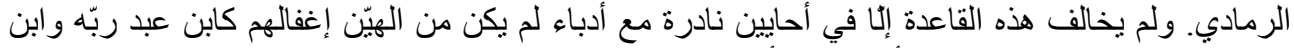

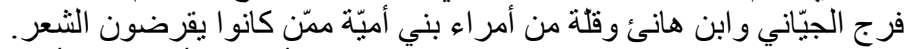

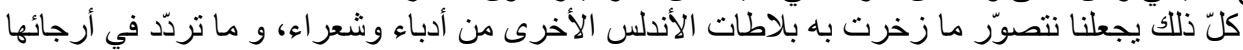

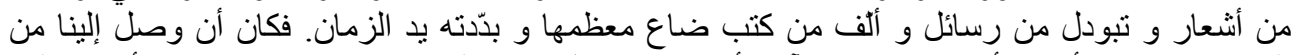

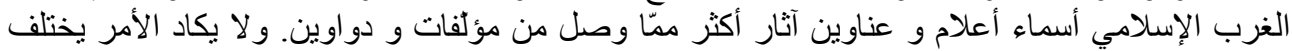

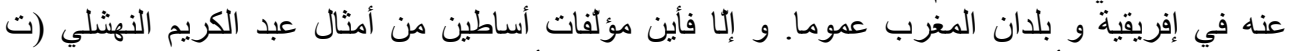

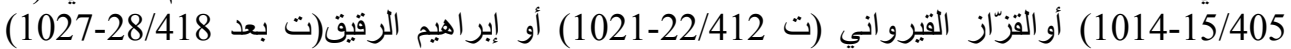

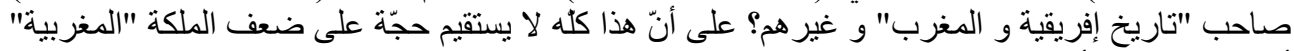
أو تواضع عطاء أدباء الغرب الإبـ الإسلاميّ.

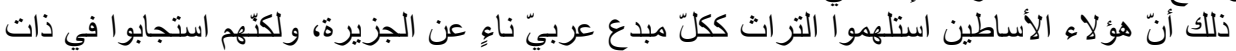

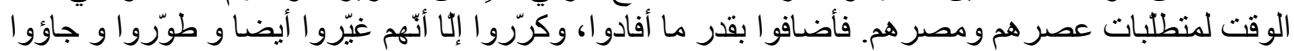

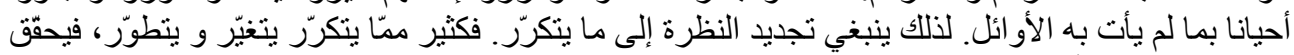

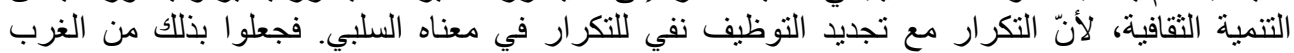

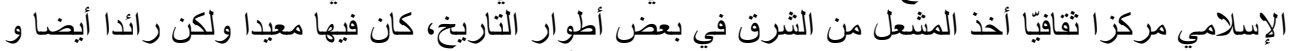

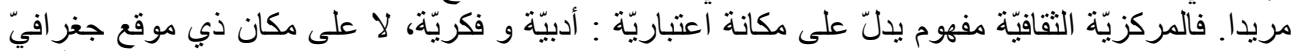

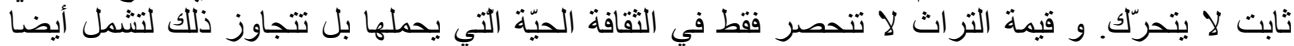

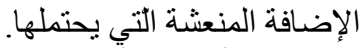

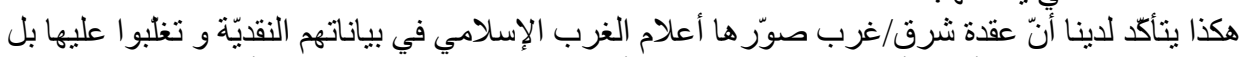

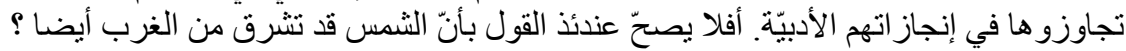

